\title{
Artefact
}

Techniques, histoire et sciences humaines

\section{Shipmasters, customs, merchants and the Russian coastal experience in the Baltic ports of the $18^{\text {th }}$ century}

L'expérience côtière russe des capitaines de navires, douaniers et marchands dans les ports de la Baltique au XVIII ${ }^{e}$ siècle

\section{Pavel Demchenko}

\section{(2) OpenEdition}

\section{Journals}

Electronic version

URL: https://journals.openedition.org/artefact/9818

DOI: $10.4000 /$ artefact.9818

ISSN: 2606-9245

Publisher:

Association Artefact. Techniques histoire et sciences humaines, Presses universitaires du Midi

Printed version

Date of publication: 7 October 2021

Number of pages: 63-87

ISBN: 978-2-8107-0755-3

ISSN: 2273-0753

\section{Electronic reference}

Pavel Demchenko, "Shipmasters, customs, merchants and the Russian coastal experience in the Baltic ports of the 18 ${ }^{\text {th }}$ century", Artefact [Online], 14 | 2021, Online since 07 October 2021, connection on 07 October 2021. URL: http://journals.openedition.org/artefact/9818; DOI: https://doi.org/10.4000/ artefact.9818

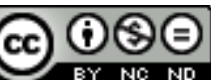

Artefact, Techniques, histoire et sciences humaines est mise à disposition selon les termes de la Licence Creative Commons Attribution - Pas d'Utilisation Commerciale - Pas de Modification 4.0 International. 


\section{Shipmasters, customs, merchants and the Russian coastal experience in the Baltic ports of the $18^{\text {th }}$ century}

\section{Pavel Demchenko}

\section{Abstract}

This article explores the specifics of commercial shipping in the Russian Empire's ports. Actors involved in commercial activities in ports are considered in the perspective of maritime experience. Custom officers, shipmasters and merchants all participated to the commercial activities and coastal experiences of the ports of the Russian Empire. The article traces the impact of spatial specifics on commercial and maritime practices in different ports of the Russian Empire, such as Saint-Petersburg, Riga, Vyborg and Narva. Because of spatial and legal aspects, imperial control of, as well as knowledge about, these ports differed significantly from one to another.

\section{Keywords}

Baltic Sea, maritime trade, ports, shipmasters, Russian Empire

95 Pavel Demchenko, « Shipmasters, customs, merchants and the Russian coastal experience in the Baltic ports of the $18^{\text {th }}$ century », Artefact, 14, 2021, p. 63-87. 


\section{L'expérience côtière russe des capitaines de navires, douaniers et marchands dans les ports de la Baltique au XVIII siècle}

\section{Résumé}

Cet article explore les spécificités de la navigation commerciale dans les ports de l'Empire russe. Les acteurs impliqués dans les activités commerciales dans ces ports à partir de leur expérience maritime. Les douaniers, les capitaines de navires et les marchands ont tous participé aux activités commerciales et aux expériences côtières des ports de l'Empire russe. L'article retrace l'impact des spécificités spatiales sur les pratiques commerciales et maritimes dans différents ports de l'Empire russe, tels que Saint-Pétersbourg, Riga, Vyborg et Narva. En raison des aspects spatiaux et juridiques, le contrôle impérial de ces ports ainsi que la connaissance de ces derniers, différaient considérablement d'un port à l'autre.

\section{Mots-clés}

capitaines de navires, commerce maritime, Empire russe, Mer baltique, ports

\section{Introduction}

Any port is a very complex phenomenon. Many people were involved in port life, including merchants, skippers, customs officials, and representatives of other local and central authorities. We know how all of them ought to operate legally, yet uncovering the "black box" of port practices yields unexpected new knowledge. This knowledge is important because it helps to understand the interrelationship between space and port practices. In this article I show how space and practices interacted in the definition of the patterns of commercial activities. 
Since the advent of maritime trade, convenient harbours and ports have become an integral part of trading infrastructures. ${ }^{1}$ The usual idea of ports as natural borders comes from the very origin of the word port - "porta" as a door or gate in Latin. Being the gates to high seas, the boundary essence of the ports is only a consequence of the terra-centric optics of the state. ${ }^{2}$ In the seventeenth-eighteenth century, states claimed to govern land holdings differently from the high seas, making a strong difference between terrestrial possession and maritime territories. ${ }^{3}$

The consideration of ports as borders ${ }^{4}$ is fully consistent with the goal of sovereignty. The state granted borders and ports with customs for a certain purpose - to levy duties, to control and suppress smuggling. As such, ports were the spearhead of power directed against the "outside" maritime world. Customs were the main instrument to tax goods and increase profits. Their objectives included the detection and registration of arriving ships, listing of goods on board, escorting goods to warehouses and settling affairs with ship captains on the one hand, and merchants on the other. However, the view of port space as a border is limited and reflects only one perspective. ${ }^{5}$

If we change our point of view - from seeing ports as borderline to considering them at the central point of a vast area with multifaceted communications among various actors - allows to reveal special conditions and many specific ports and coastal practices. A port was not only a space. It mostly consisted of people and their activities. These hubs of commodities, networks, people and money were vital entities with their practices, laws and ways of development. Ports were functioning not for someone's profit, but because of common benefits. The prosperity of all port actors reflected the ports' fate. State income depended on merchants' profits and the state's ability to manage these maritime "boundaries".

The empire's role in accounting for and describing the commercial activities in the coastal space was not primary for the ports. From this point of view, accounting and recognition by customs was a self-translation process, and every port infrastructure was a kind of unknown vital entity or "black

1. Benton and Mulich, 2015, p. 151-172.

2. Benton, 2010 .

3. Mulich, 2013, p. 72-94.

4. Wei Leng, 2009, p. 25-37.

5. Wenzlhuemer, 2016, p. 163-186 ; Jarvis, 2010 ; Alcalde, 2018, p. 553-567. 
box". At the same time, there were practices of concealment and agreements, as a reverse side of the agreement to join the port by commercial actors. If someone was not satisfied with the terms of trading in the port, disappointed actors (merchants, shipmasters) could violate port rules. The possibility to violate rules depended on the ports' location and geography, so geography became one of the factors from which ports got their shape.

Also, such a change of perspective allows us to separate the lower-ranking authorities on the ground from the senior imperial ones. Such heterogeneity breaks the analytical framework of the "state" and makes it possible to examine state-affiliated institutions and authorities in a particular way. Since the description of commercial activities was carried out by lower ranks (customs) and authorities in close competition and cooperation with the shipmasters and merchants, it is logical to combine them into a "port environment" or coastal experience. The history of most European ports shows us the close relationship of customs and port officials with merchants, which allows us to consider them as equal and to unite them within one frame. ${ }^{6}$ Customs and merchants produced knowledge that would be designated as internal. This knowledge and information about themselves were largely internal, despite the desire of higher authorities to access it.

A similar approach is presented by the new coastal history, ${ }^{7}$ in which the coastal experience is central. This approach was proposed by Isaac Land in his review "Tidal Waves: The New Coastal History”. There he suggested to look at the stories located onshore, but not in the high seas or overland. Coastal zones are considered not as a border between land territories and sea spaces, but rather as the center of a specific experience of human culture and life. ${ }^{8}$ The new coastal history is a mixture of different approaches, united by a special coastal experience and therefore imposing characteristic features for all coastal spaces around the world. So the main idea is to consider this coastal space as a full-value space, not just a derivative borderland of terrestrial and maritime spaces. This coastal space contains its own patterns. In my view, ports fit perfectly into the concept of the new coastal history, which outlines an important space for my research. Thus,

6. Mulich, 2013, p. 72-94; Domhnall Uilleam Stiubhart, 2017.

7. Stock, 2015.

8. Land, 2007, p. 731-743. 
in this article, I consider a special coastal space - ports, activities there and the efforts of the state to recognize, change and control this space.

In this article, I observe the interrelation between space and practices in the Baltic ports of the Russian Empire. The key question is: What was the impact of space and practices on the port space? The use of the framework of coastal history helps us to consider ports as a unique place with their own unique coastal experience. Such a focus allows us to observe ports as a central place, not as a gateway or membrane between unmanageable ocean space and state lands.

To understand the complex reciprocity between the local geography of ports and people's practices there, I studied numerous visual sources such as maps, pilot charts, drawings of the ports. Also, I examined litigation cases between merchants, customs, town magistrates and state collegiums. Several reports were analyzed from the collections of the Collegium of Commerce and the Commission about Commerce from the Russian State Archive of Ancient Acts (hereafter RGADA). These materials provide valuable information about practices in ports and were selected as evidence of disclosed hidden practices. These practices are crucially important for my study as they depicted the activities as process of delimitation of legal and admissible activities in common port space for all actors. Interpreting these cases as process of mutual management of common space I show that the port geography and commercial actors' activities were in coexistence and interrelation. But most importantly, it became possible to settle coastal practices on maps and analyze them in a special dimension. It allows to trace the capabilities and limits of the "maritime" commercial community" beyond imperial control. Also, it helps to consider space management through the prism of spatial and social aspects. ${ }^{10}$

After the Great Northern War, the Baltic shore was finally acquired by the Russian Empire. The coastal experience of the Russian Empire was radically transformed in the eighteenth century. The Russian Empire seized the old East Baltic ports with already deeply-rooted infrastructure such as Riga, Reval, Vyborg ${ }^{11}$ and St. Petersburg (founded close to the former Swedish

9. Vickers, 2007; Redicker, 1987; Reid, 2020.

10. Lefebvre, 1974.

11. Vyborg was the fortress and significant port in Swedish Finland. It was captured in 1710, aiming to ensure security for the newly established capital Saint-Petersburg. Borodkin, 1910. 
fortress of $\mathrm{Nyen}^{12}$ ) on the easternmost part of the Gulf of Finland. These port towns had not only their specific history but also special relationships with their previous sovereign - the Swedish crown. The Russian Empire inherited this medieval yoke of old treaties ${ }^{13}$ and agreements in order to pacify the newly acquired territories. It was one of the conditions of the Treaty of Nystad, that ended the war in 1721. This strategy of preserving parts of the "old order" as autonomy ${ }^{14}$ in Baltic provinces of the Russian Empire (hereafter - the Baltic provinces) preserved different power structures from the rest of the Russian Empire.

Baltic ports were the point of destination of many goods. ${ }^{15}$ A great number of these goods originated from East European stretches (Polish-Lithuanian Commonwealth, Prussia and Russia, etc.) and were steered to the ports on the Baltic shore (Riga, Danzig, Konigsberg, Reval ${ }^{16}$, etc.), where there were market sales. ${ }^{17}$ Thus, the newly acquired Baltic ports did not shape a fully common market with older Russian holdings. Until the eighteenth century, a significant part of the Russian territory was focused on trade via Archangelsk ${ }^{18}$ because of Swedish dominance and heavy taxes in ports under the Swedish rule. ${ }^{19}$ Three reasons - the market, local political auto-

12. In the time of the Russian conquest of Ingria, the population of Nyen was evacuated and the town was burned down to amend the defence of the Nyen fortress.

13. As far as we can trust the petitions of Riga's merchants, they consider numerous old Swedish taxes as a reason of their bankruptcy and impossibility to trade and collect taxes in fill volume. Based on these complaints, Czarina Katherine II issued the Statute for Riga's commerce in 1765. According to it Riga's magistrate lost his rights to impose additional duties and taxes. Also, some of the old Swedish taxes were revoked. Complete Collection of Laws of the Russian Empire $\mathrm{n}^{\circ} 12518$. Statute for Riga's commerce. The rest of old Swedish taxes was cancelled later (when the Riga province was replaced by the Riga viceroyalty) and due to the composition of common western customs border of the Russian Empire (the customs tariff of 1796). Lodyzhensky, 1886, p. 156.

14. Kozlova, 1999, p. 114.

15. Biskup, 1978, p. 293-314; Soom, 1963, p. 184.

16. Nekrasov, 1984 ; Elias, 1967, p. 16-28.

17. Brenner, 1976, p. 53-60 ; Cieslak, 1983, p. 239-270; von Loewe, 1973, p. 23-37; Tielhof, 2003.

18. Bespyatykh, 2010.

19. Some Russian merchants traded via Reval, Narva or Nyen, but Russian merchants were not in favour and had to trade only with Swedish intermediaries. Direct trade with foreigners was banned according to the conditions of the Treaty of Stolbovo, but at the same time Russian commerce on the Baltic shores remained trough merchant networks. Shaskolsky, 1968, p. 59-68 ; Rukhmanova, 1957, p. 52-58. Also, the Great Northern War broke off the remained commercial ties between Russian holdings and Baltic ports under the Swedish rule - Russian merchants were forced to trade via Archangelsk since 1701, and then via Saint-Petersburg. Zakharov, 1996, p. 103 
nomy and the prevention of smuggling - forced the Russian Empire to set the customs border between the Baltic provinces and the Russian provinces in the eighteenth century.

Firstly, most of Russian goods had to be sold in newly established SaintPetersburg. ${ }^{20}$ The new capital was promoted as the main commercial port of the Russian Empire ${ }^{21}$ and possessed benefits that other ports connected with western markets did not have. While the ports of Riga and Reval were viewed by Russian authorities mostly as a source of income, the modernisation of the port of Petersburg became a challenge. Here is the main difference between these ports. The management of the Baltic provinces' ports was limited to military control of the borders at first. ${ }^{22}$ No changes in the Baltic provinces could be made without the local self-government and nobility's approval until the reign of Catherine II. At the same time, far more important questions troubled the imperial authorities in the Baltic ports under their direct control. Major Baltic ports under direct imperial control were Petersburg and Vyborg. Riga and Reval had their town councils and local autonomies, while Narva's situation changed: its attachment changed from Petersburg to the Reval province. ${ }^{23}$ And if imperial authorities relied on former custom authorities in Vyborg where there was also Swedish legacy without autonomy, in Petersburg they had to build a new port.

In the age of cameralism and Enlightenment, the Baltic ports became for the Russian Empire both profitable and modernizing spaces. For these reasons the imperial authorities were sensitive to maritime commerce. And while the Baltic provinces ports were mostly considered as a source of state income, the territories of the ports of Petersburg and Vyborg were being

\footnotetext{
20. In the period 1711-1721 there were struggles between the authorities and merchants on the question of where goods could be shipped - only in Petersburg, or as well in Archangelsk. Zakharov 1996, p. 133. Since 1721 merchants were banned to transport any goods to Archangelsk except goods from the Pomorje region - the shores of the White sea and the Artic ocean. Demkin, 1998, p. 17. Later this policy of Petersburg's commercial privileges was abolished only in 1762, but Petersburg remained as the main Russian port.

21. Keenan, 2015, p. 97-124; Attman, 1981, p. 192.

22. Seppel, 2009, p. 286. Later, in the 1760s, the imperial authorities encroached on local politics. 23. Narva was located on the borderline between the Reval and the Petersburg province, therefore, the town's submission toward Reval or Petersburg changed with administrative reforms. From the conquest till 1727, Narva was part of the Peterburg governate, then became part of Reval's governate and local autonomy. Also, the fortress of Ivangorod became a purlieu of Narva.
} 
negotiated between imperial authorities to increase the commercial profits of all actors. Because of different port regimes, all actors in the ports were trying to change the status of their ports and of the hinterlands. While the imperial authorities were eager to reduce the autonomy of the former Swedish possessions, local town authorities tried to negotiate with the imperial centre to increase their profit in their port. On the other hand, some customs officers tried to ease their service or increase their profits.

The objects of my study are the Russian ports on the Baltic sea during the eighteenth century. First of all, these are St. Petersburg, Riga, Vyborg, Narva and other minor ports. Each port had its unique features imposed by the local conditions and laws, geo- and hydrography, local authorities and its distance from imperial institutions (imperial Collegiums, the Navy, state borders). The central question is how the imperial authorities and commercial actors understood and tried to interact with each of the port's characteristics and their unique environment.

Hereafter I study three topics that were common issues among Russian ports on the Baltic sea. The first topic unveils the specific impact of local hydrography on ports' spatial practices. The second topic considers the contradiction between different customs in each port. And the last topic is dedicated to ports as places of common interest and compromise.

\section{Sea passages and local hydrography}

The Russian ports in the Baltics differed from the other Russian ports not only because of their legal regimes, customs and political institutions but also because of their hydro- and geography. Hence the need to study the local practices caused by spatial specificities. For example, Riga and Narva were located deeply onshore whereas Petersburg was located at the shores of the Finnish Gulf, and the port of Vyborg was located neither on riverbanks nor on the Baltic shore: ships had to sail far into the sea cliffs to reach the port.

Because of its local hydrography, the port of Vyborg did not fit into the conventional scheme. Located not on the open coast but deep inside the skerries, the Vyborg port could be reached only through one narrow sea passage. From the point of view of central officials, the location of Vyborg's port location was not convenient. Through a narrow tideway, ships had 
to pass along the Trongsund fortress. The gateway to this sea passage was a narrow passage near Rogel Island. Thus, because of the presence of a military fortress at the narrowest sea passage to the port, the Vyborg port authorities could easily control merchant shipping. However, the Vyborg customs officers had a different opinion on the subject (Fig. 1).

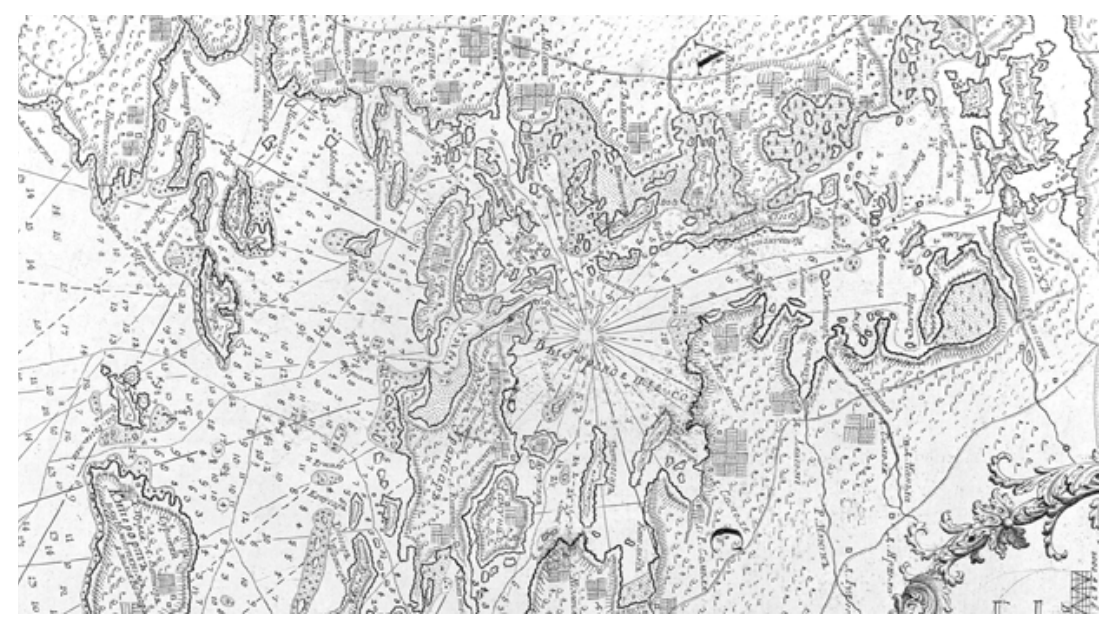

Fig. 1. - Naval map of sea passage to port of Vyborg. Morskie chastnie karty korelskikh I finlandskikh beregov

$\mathrm{SPb}, 1789$, Public domain

Local customs officers considered Vyborg as the main port of the Finnish lands and tried to increase their profits. Thus Vyborg customs officers asked for the permission to relocate the customs outposts far into the seawaters several times. ${ }^{24}$ The main motives were to increase the popularity of the Vyborg port on the one hand and to establish stricter control on the other. Customs officers in charge noted the following problems: firstly, it was not convenient to levy duties and register ships in the Trongzund Strait, since in this narrow strait anchored ships were at risk to be smashed against rocks and the shallow shore. Secondly, wardens complained that merchant ships were unloaded at numerous sawmills on the coast and bays. For this reason, they proposed to relocate the outpost on the island of Rogel. Also, local customs officers proposed to change the customs taxation of goods arriving from Sweden to make Vyborg the main port for the wholesale of 
Finnish goods. This was in the personal interest of customs officers: according to the law, part of the taxes was the customs officers' profit. Due to the impossibility of revising the duties' share, they tried to increase the volume of goods and registered ships. ${ }^{25}$ However, the Collegium of Commerce refused the proposal of the Vyborg customs officers. But the real reason for refusing was imperial distrust ${ }^{26}$ and suspicion ${ }^{27}$ toward customs officers, so they had to continue to levy duties at the fortress of Trongzund.

The situation in Riga was similar but differed in some key aspects from that of Vyborg. The port of Riga was a black sheep among all other ports of the Russian Empire. First, the local Ostsee law gave its specifics. Custom duties at the port of Riga were based on local legislation, not on the imperial one. As a result, we see the difference even in the word used to label the local customs - Licent-Kontor. ${ }^{28}$ Until the 1780 s and the general reform of the Russian customs border, the old duties at Riga remained untouched from the Swedish period. Second, a completely different geography also left its mark on Riga's coastal experience. There was only one entrance to the port of Riga, located in the waterway of the Daugava, from the Gulf of Riga through the outflow of the Daugava. The river mouth was protected by the fortress of Dunamünde, where the first customs checkpoint was located (Fig. I, colour plate). There were no patrols of the Gulf of Riga, which shows that the authorities were confident that the customs post in Bolderaa was successful with its tasks. Of course, this lack of patrols could also point to the ignorance of imperial authorities about the local conditions in the Gulf of Riga.

However, despite the fortress cannons, which were supposed to intimidate shipmasters and have them stop and pay their port tolls, nothing stopped many of them from unmooring at night and sailing away without paying the tolls. This practice is mentioned as common in the Licent-Ustav ${ }^{29}$ of

25. RGADA, coll. 276, inv. 3, f. 122.

26. RGADA, coll. 397, inv. 1, f. 575. There is more evidence in the files of Collegium of Commerce. Usually, the Collegium of Commerce tried to supervise the customs with the help of inspectors or Commissions of customs. The participants of these surveys usually complained about customs servants, blaming them as thieves and henchmen of smugglers.

27. Korchmina, 2017, p. 287-310.

28. Complete Collection of Laws of the Russian Empire n ${ }^{\circ} 4443$. About establishing the Academy of science and supplying it with toll income from Narva, Derpt, Pernov and Arensburg Licent-kontors.

29. Complete Collection of Laws of the Russian Empire n ${ }^{\circ}$ 13118. Licent-Ustav of Riga, 1768. 
Riga, the instruction for customs service, by merchants and shipmasters who wanted to trade in Riga. The relationship and customs practices that prevailed in the port of Riga between skippers and merchants was very different from those having course in other ports. The port of Riga was more vulnerable to the impudent secret departures of shipmasters. Since there was no external guard ship, the fortress did not threaten commercial ships with its guns (as it did in Elsinore, for example), captains could leave without passports. At the same time official's attempts to find them by observing correspondence or surveying were vain.

Narva was initially one of the most important maritime ports for the Russian provinces. In the first half of the eighteenth century the port of Narva had significant ship traffic with ports outside the Baltic Sea. ${ }^{30}$ However, Narva's role diminished by the middle of the eighteenth century, and it became one of the many "satellite" ports of St. Petersburg. Therefore, some merchants of Narva moved to Petersburg, bought houses in the city and claimed themselves as merchants and dwellers of both Narva and Petersburg, claiming trade rights as Russian merchants. ${ }^{31}$ At the same time Narva remained a convenient harbour, so when shipmasters could not reach Petersburg due to ice or inclement weather, they stayed in Narva and unloaded cargo for Petersburg in Narva's warehouses. Also, commercial shipping was based on the remnants of sustainable trade networks.

The spatial organisation of Narva's port was close to that of the port of Riga. Both ports were located deep inland (about $12 \mathrm{~km}$ ) (Fig. 2). The first customs outpost was located in the village of Magerburg on the right bank of the Narva river's mouth. ${ }^{32}$ There were customs, a small harbour and warehouses for registering and keeping goods unloaded near the vil-

\footnotetext{
30. I compared the ship traffic of ports under Russian rule using the Sound Toll Registers Online database. According to my calculations, until the 1740s Narva and Petersburg had comparable number of ships, each dominating in different years (these calculations do not include internal Baltic shipping, only trans-Sound shipping). But after 1740s Narva was no longer comparable in ship traffic to Petersburg.

31. RGADA, coll. 276, inv. 3, f. 145. All Russian subjects had different right regimes. Similarly, merchants and dwellers of different regions had different customs, permissions to trade or prohibitions. In this case it seems that the merchant Arnse wanted to get both benefits of being as a core Russian merchant and Narva's dweller to trade in Petersburg (to get more trade rights) and possibly avoid the customs border between the Baltic provinces and the core Russian provinces. Semenov, 1859, p. 145.
}

32. RGADA, coll. 276, inv. 3, f. 211. 
lage. The customs house was located in Narva on the Estland's bank and usually was pictured on maps as "merchant jetty". Because of the long way up by the river from the first custom point to the custom house in Narva, a custom patrol had to secure and prevent the illegal unloading of goods on the riverbanks and seashore of the Petersburg province.

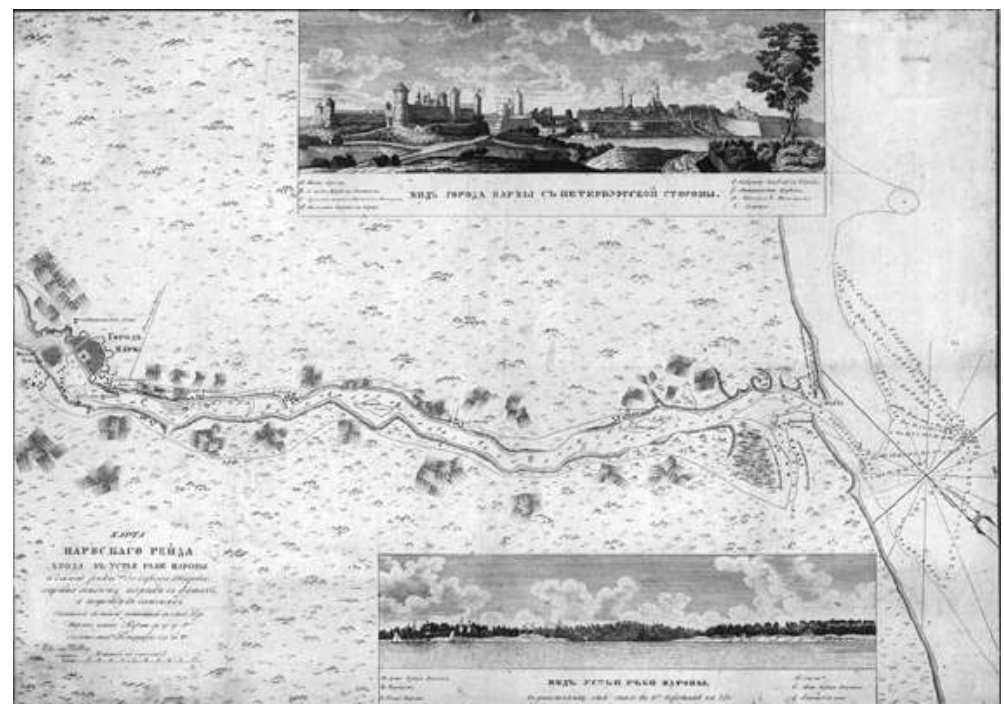

Fig. 2. - Map of Narva's seaside

\section{Museum of Narva, Public domain}

Petersburg became the most recent port of the Empire. The Russian authorities could build there, on the newly appropriated land, whatever they considered useful. And here was the strongest customs border. It was not only because Petersburg was the capital port, but also because of its specific location. There was a vast seashore where smugglers could easily unload their cargo. Since the 1720s-1730s Petersburg had three customs checkpoints. ${ }^{33}$ The aim was to seek and guide merchant ships to the port of Petersburg without any possibility to unload anything along the way. But still, many captains and merchants exploited the Russian customs' inexperience and lack of resources. There is ample evidence of unloading of

33. Petersburg and Kronstadt had a joint custom border. The second custom check was located in the Kronstadt, where a lot of ships unloaded their cargo on barges on the way to Petersburg. 
goods on the banks of Neva before imperial eyes. ${ }^{34}$ This was very similar to practices of escaping captains at Riga port, but at Riga port the reason was the absence of real control on the Daugava river, whereas in Petersburg it was due to difficulties in managing the limited space of the Neva river, with a large number of actors willing to cheat.

It is important to understand the differences regarding spatial aspects before we set practices on the ground. The Customs of Petersburg and Vyborg had stricter control than the customs of Riga and Narva. But at the same time, the Collegium of Commerce did not trust customs and relied on the army or on navy ranks. The permeability of the imperial border differed a lot. It was easier to cheat on the customs of Riga or Narva or hide the unloaded goods in sea cliffs close to Vyborg. In Petersburg, captains exploited the geography of the imperial capital to confuse the authorities.

\section{Customs as legacy and modernization}

As mentioned above, autonomy from Swedish rule in the Baltic provinces remained. This autonomy saved many tolls and duties in the ports of the Baltic provinces. ${ }^{35}$ Until 1768 the Russian Empire did not get into the inner commercial affairs of the Baltic provinces closely. The Baltic provinces kept their customs, tariffs, municipal government and magistrate. The changes came only in 1765, when the Commerce Statute of Riga was enacted. In 1768 the Licent-Ustav ${ }^{36}$ was issued by Empress Catherine II as a new legislation for the port of Riga. But before this moment, there were completely different customs in the Russian Empire. In this paragraph I study the variety of customs in the Russian ports of the Baltic sea.

As already mentioned, the Baltic provinces of the Russian Empire did not become an integral part of the Russian customs territory. ${ }^{37}$ In the eighteenth century it was an autonomous territory with local and Swedish legacy. In the 1740 s, a proposal came from the Riga Magistrate to the Collegium

34. RGADA, coll. 276, inv. 3, f. 127. Here the shipmaster Gumb was imprisoned for unloading the clothes in the night. Gumb was not alone in his intention, for example the shipmaster Peterson tried to unload some of his goods onshore near the merchant houses, but failed, escaped and left his crew and ship. RGADA, coll. 276, inv. 3, f. 189.

35. Except one additional toll 13 kopeck from ruble. Semenov, 1859, p. 142.

36. Complete Collection of Laws of the Russian Empire n ${ }^{\circ}$ 13118. Licent-Ustav of Riga, 1768.

37. Kamusella, 2013, p. 815-838; Wezel, 2017, p. 39-54. 
of Commerce regarding permission for Jews to bargain Lithuanian and Polish grain in Riga. The magistrate motivated the removal of the restriction from Jewish merchants by the fact that significant goods, which could potentially be sent to Riga, flowed to other ports. It was inconvenient for merchants to trade in Riga because of these restrictions. This issue was especially acute given the competition of Riga with Koenigsberg as a trading hub. The local magistrate saw a threat to the prosperity of Riga's trade. This can be distinguished as a common feature of the newly acquired ports in the Baltic Sea, which wanted to maintain their former commercial ties. Their knowledge and understanding of their trade were different from those of the imperial Collegiums in St. Petersburg.

The Collegium of Commerce regarded the role of the port of Riga mainly as a source of state income. ${ }^{38}$ The port's focus on transfer trade was not particularly developed, and the organization of customs in the port of Riga took place outside the imperial institutions. Until the 1780s and the organization of a single customs border, the main imperial institutions were outside the process of knowledge production. To a great extent the local authorities kept control over the commerce in the Riga port in their hands. ${ }^{39}$ Therefore, the Imperial government bodies, like the Collegium of Commerce, apparently had rather limited knowledge of the situation in this port.

A similar story occurred in the port of Vyborg. Local customs wanted to attract all Finnish goods to be sold and shipped in Vyborg. The Collegium of Commerce refused. It is possible that the Collegium of Commerce did not want to go into details, or wanted to save the status quo with custom control under military authorities. Although, most likely, the customs officers wanted to some extent to restore the trade routes of the Swedish period, which had been interrupted by the establishment of a new border after the capture of Vyborg. The issue of wholesale markets and its recovery was also to be taken into account after the Northern War of Frederikshavn which was a convenient harbour in Sweden (till the 1740s). The Collegium of Commerce replied that since there were no people ready

38. Despite merchants' willing the Commerce Collegium several times refuse to allow Jewish merchants from the Commonwealth to trade in Riga, for example. Also, the imperial authorities concern about Riga and Konigsberg competition as trade ports can be hardly found till 1760s.

39. Complete Collection of Laws of the Russian Empire $n^{\circ} 2278$. Contractual clauses proposed by the deputies of the city of Riga on its surrender and entry into Russian citizenship. 
to serve at supposed outposts, the question did not make sense. I suppose two explanations are possible here: either the Collegium of Commerce did not want to transfer the customs outpost from the military fortress, or there were financial reasons for this decision. No one wanted to bear the costs of establishing and maintaining regular patrols between Rogel Island and Peysar Island.

Here we do see multiple actors, who defined the coastal experience in the port of Vyborg. The relationships between merchants, shipmasters, customs, local hydrography and specificity of the local navigation explain the success of the port in Vyborg. This port, as well as others, took shape because of its unique experience. Ships unloaded in shallow bays at sawmills without the supervision of customs officials, while decisions regarding ships unloading legally were driven by more pragmatic concerns. Based on the legislation, the main consideration of customs officials was how to maximize their profit. If the legal duty provided less profit than that which was attained through unofficial bribes for illegal unloading at the port, it allowed shipmasters to illegally unload goods. This was probably one of the reasons why the Collegium of Commerce did not want to transfer the customs outpost from Trongsund. Officers of the Admiralty who served the Trongsund fortress, traditionally had a negative attitude towards entrepreneurs. Therefore, they often accused them of fraud and forgery of documents. In particular, several times during the eighteenth century, officers of the Admiralty disclosed illegal forged schemes. ${ }^{40}$

Narva was located on the edge of two custom territories - the Russian (centred on the port of Petersburg) and Baltic territories. The Narva river became the internal border between different duty territories. Therefore, there were two different customs institutions here in the first half of the eighteenth century. There were customs collecting tolls from shipmasters and overseas goods, and internal customs collecting tolls from goods transported between provinces as well as Baltic and Russian provinces. The ports of Estland and Livland had their own lower tolls since they had adhered to Swedish law and therefore remained on the customs' books in those provinces. Therefore, lots of merchants and shipmasters were trying to unload their goods in ports where they could pay less custom taxes. So, if shipmasters or merchants wanted to unload goods for Petersburg in Narva 
(it was also a frequent situation because of ice in the port of Petersburg), they had to pay tolls twice - for both external and internal customs duties.

Both customs were close to each other, which caused disagreements and quarrels between customs officials, the magistrate and the commandant of the town. The main reason for disagreements was the fact that the inner custom was under the supervision of a magistrate and the Kamor-Collegium, while the outer custom was under the jurisdiction of the office of the Director of the Narva Customs House, who answered to the Commerz-Collegium, a different ministry. At the same time, both customs shared common space and resources. In addition to thefts and concealments, there were lots of conflicts upon jurisdiction and seniority. For example, the town commandant attempted to dismiss warding soldiers from customs, ${ }^{41}$ necessary documents were sometimes concealed from the magistrate's office by the customs office, and toll revenues were hotly debated. ${ }^{42}$

The port of Petersburg had other spatial infrastructure and practices. Customs officers tried to unload goods from vessels, without waiting for the owners to keep pace of unloading process. ${ }^{43}$ Otherwise, goods could not be transferred to warehouses in time and it caused traffic jams in waterways. Transferring goods to warehouses was the most painful part. Shipmasters stated that the goods had been unloaded from their ships in good condition, while merchants usually wanted to blame somebody for the lack of accuracy of the goods. Against this, instructions targeting shipmasters for improperly unloading cargo or the discovery of any imperfections would absolve Customs officials. ${ }^{44}$ There was a long procedure to load or unload goods on ships. Thus, captains often tried to reduce the waiting time at the port. For example, captains unloaded goods "according to the order" without specifying the address so that they did not wait for the merchant to accept the goods. It was because no one excepted the merchant could accept the invoice - the actual contents of the goods.

\footnotetext{
41. RGADA, coll. 276, inv. 3, f. 152.

42. RGADA, coll. 276, inv. 3, f. 127.

43. Complete Collection of Laws of the Russian Empire $n^{\circ} 16244$. About keeping 50 surveyors for unloading and uploading goods.

44. Complete Collection of Laws of the Russian Empire $n^{\circ}$ 9407. About non acceptance of goods abroad in the Customs and revision if the Customs Law of 1731.
} 
At the same time, despite the stricter regulation of the customs order and the presence of many imperial institutions, the port of St. Petersburg also had many problems. One of the most striking cases in the hidden life of the St. Petersburg port was the case of the investigation of illegal export of military scrap ${ }^{45}$ and escapes of prisoners for violations against law shipmasters. ${ }^{46}$ The trial went on for a long time, however, no one was punished. Merchants disappeared, none of the Admiralty pleaded guilty to the sale of military property. Also, drunkenness was a common problem for soldiers in customs duty. ${ }^{47}$ This led to secret deals onboard and illegal unloading of goods.

In St. Petersburg we observe a completely different situation from that in Vyborg and Riga. In St. Petersburg, the proximity of the central imperial institutions made the latter closer to commercial activities in the port. These imperial institutions were the military naval guards and the Admiralty, the Academy of Sciences, which published statistics of incoming and outgoing ships ${ }^{48}$ the customs, warehouses and a large guest yard located on Vasilievsky Island next to the imperial colleges. However, the clandestine life of the St. Petersburg port was hidden from the formal eyes of the College of Commerce. Besides, the customs were often outsourced, ${ }^{49}$ which prevented imperial institutions from producing knowledge about the port. The situation began to change in $1763^{50}$ with the creation of the Main Office to oversee all others - from this time on, we can talk about a single customs management, since earlier each customs office was directly subordinated to the Collegium of Commerce and the Senate. However, this did not change the basic logic of the Empire toward the ports. For the empire and its logic of mercantilism, fiscal interests and cash flows were important. Accordingly, the knowledge that the empire tried to produce about commerce in ports bears the imprint of its formalized standardization. However, the empire itself did not produce legal knowledge, for economic and geographical reasons. The knowledge of commerce in ports was

45. RGADA, coll. 397, inv. 2, f. 21.

46. RGADA, coll. 276, inv. 3, f. 127.

47. RGADA, coll. 276, inv. 3, f. 51.

48. The newspaper "Saint-Petersburg Vedomosti" was printed in the typography of the Russian Academy of Science. Usually the information of shipping was located in the end of each volume. 49. The right of collecting tolls was usually sold by state to certain people for prescribed price. The practice was close to the French Ferme Générale.

50. RGADA, coll. 397, inv. 1, f., 159; RGADA, coll. 397, inv.2, f. 10. 
created by all actors (merchants, customs, shipmasters, authorities) operating in the coastal territory. The vision of commerce in the port depended on certain agreements dealt between numerous participants of the commercial activities. Other participants were either involved in creating an image of trade or they had to recognize it as a reality. Due to the lack of imperial control, participants to commerce always had an the possibility to hide their activities. It also reflects the alliances and agreement set up in the ports. The lack of knowledge is also the result of the production of knowledge, or rather its concealment, as was the case with captains in Riga, or owners of sawmills near Vyborg, or smugglers and "petty traders" in St. Petersburg.

\section{Ports as places of compromise}

The third topic considers ports as places of agreement. According to the usual view, ports are a gateway or just a hub, which reduces our capability to understand port as a valuable place for the coastal experience and not just as frontier or borderline. For the Russian Empire, it was one of the main sources of human experience and chance to widen this experience. The imperial authorities figured out that ports were not just a place to trade, but a place of local agreements and conventions, where most of the affairs were dealt behind the scenes and not just only on formal ground.

The convention was based on people's practices and local geography. Despite harsh Russian laws, many merchants and captains were freed from fines and punishments in order to keep the common agreement around the commerce between imperial authorities, merchants, captains and their ship crews, customs. Some of the problems were for a long time ignored by imperial authorities: ${ }^{51}$ for instance, the nightly escapes of captains in Riga without paying tolls, the illegal unloading in sea cliffs near Vyborg, the smuggling in the centre of the imperial capital.

While merchants were sorting out goods and picking them up from warehouses, skippers had to stay anchored in the Neva river. This resulted in the emergence of petty trade at St. Petersburg's port. Curiously, during the eighteenth century several attempts were made to legalize the "petty trade"

51. Struve, 2016, p. 82. 
of skippers and sailors. ${ }^{52}$ The first time the legalization was initiated by the Admiralty. However, the Collegium of Commerce opposed it. The second time, the Collegium initiated the proposal, but the magistrate resisted. The magistrate was not satisfied with unauthorized trade in the city, so he tried to ban it. Besides this, the Collegium of Commerce thought that it was impossible to keep petty trade under control or ban it, and so it tried to direct this trade into legal channels for taxation.

Even customs themselves violated tariffs and legislation. In the middle of the eighteenth century the director of Petersburg custom house argued that if they levied full duties, then most of the merchants would not unload at ports but would go to skerries or uncontrolled bays and unload goods there illegally. ${ }^{53}$ This would lead to shipwrecks (shipwrecks of smugglers were quite frequent, since hiding in the skerries might lead to breaking the hull against the underwater cliffs), ${ }^{54}$ which would further reduce the enthusiasm of merchants to keep commerce and revenue from duties.

All actors in the coastal zone were equal to some extent. In Narva the magistrate was trying to attract garrison chiefs to oppose customs officers, while customs in Vyborg tried to evade military control. The merchants and town authorities in Riga did not mention those who fled away without paying tolls. The merchants of Petersburg kept good relationships with authorities to solve their problems. And if we use the perspective of coastal experience - it is no longer the story of corrupted hide and seek, but the story of local alliances in ports. The spatial analysis helps us to locate these alliances and relationships in order to understand what the exact coastal experience was.

\section{Conclusion}

Ports are traditionally supposed to be the edge or vanguard of the empire. Instead, in this article, they turn out to be the center of coastal experience

52. Complete Collection of Laws of the Russian Empire $n^{\circ} 15033$. About permission for foreign shipmasters and sailors to petty trade.

53. RGADA, coll. 397, inv. 1, f. 569. Case about the writing on 122 pages to supervisor Nikita Shemyakin with companions of delinquent payment. Here the former Chief inspector Shemyakin insisted that maritime commerce declined because of the great fire in docks of Petersburg: merchants are afraid for their ship and for local trade.

54. RGADA, coll. 276, inv. 3, f. 122. 
and valuable spaces. The reason why ports have become the edge of the empire in the eyes of the central bureaucracy is perhaps quite pragmatic. Based on the logic of cameralism, the Collegium of Commerce cared primarily about the accumulation of money. This can be seen both in the example of Vyborg and Riga. The Commerce Collegium tried to rely on imperial institutions, primarily taking care of collecting coins for the realm, not developing ${ }^{55}$ trade. Together with the cameralist idea of increasing export with the help of growing industries, commerce was regarded as a given. Customs officers and magistrates wanted to increase personal profit, merchants to avoid tolls and save goods in proper condition, shipmasters to unload cargo quickly without spending time, while the military suspected the other participants.

This approach of combining commercial practices and the spatial dimension on the ground shows the unique practices of commercial actors due to the different geographical conditions and various legal and right regimes in the Russian Empire. The Russian Empire was not a homogeneous territory, therefore different regions of the Empire shaped their peculiar pattern of commercial and social activities. Even in the nineteenth century regions differed significantly (e.g. there were special Siberian coins only for Siberia). Participants to commercial activities could not ignore local natural and geographical aspects, so they had to adapt to these aspects to fit into them.

The geographical conditions impacted commercial activities and their participants. This was proven by different practices amidst the Russian ports on the Baltic Sea. This difference in perception of coastal experience among actors negatively affected the organization of common space. If in St. Petersburg authorities constantly tried to regulate practices, they still could not succeed. Widespread intervention inside the coastal zone began only in the 1760-1780s when the Empire decisively forbid the practice of outsourcing customs, when all customs were integrated into one structure. Only after the unification, the greater Empire's involvement in the coastal experience with a complicated system of alliances, relations and practices became possible. Before, the Russian customs could appropriate new borders through attempts of state border control, private leasing of customs and permanent search of illegal unloading went on. Space became one of

55. Struve, 2016, p. 84. 
the significant actors, because the imperial power was not able to manage borders successfully. In every port the imperial authorities, as well other participants had to frame their activities according to the local geography. Practices in the Russian ports on the Baltic sea differed because of different geographical, legal and right regimes. But the imperial logic did not change at all from the previous one. The Empire still did not open the "black box" of ports - the hidden agreements between the different actors (customs, merchants, sailors). However, the Empire was not interested in it. For the Empire, ports remained mostly frontiers and gateways to fiscal policy.

In conclusion, I would like to note that there are much more issues about ports that can be studied within the frame of coastal experience and spatial analysis. Only part of the Russian Empire's concerns toward ports were presented here. The spatial impact of the practices is very important while studying the local "black box", because practices and relationships between actors were very different from one port to the other. It affected the coastal experience and even when the geographic aspects were the same, results were different, depending on alliances and relationships between actors.

\section{Sources}

RGADA, coll. 276, inv. 3, f. 127. Report case of Petersburg port customs' about shipmaster Gumb's fine for cloth stolen from ship, his escape from customs and capture in Kronstadt, deportation from Russia and restriction to arrive once more. 1727. Дело по докладу СПб портовой таможни о положенном на шкипера Гумба за снос с корабля сукна штрафу, и о побеге из таможни и о поимке в Кронштадте и о высылке из Росси и чтоб впредь не въезжал.

RGADA, coll. 276, inv. 3, f. 152. Report case of Narva port customs about removing guards by commandant from that customs. 1729. Дело по доношению нарвской портовой таможни о своде от той таможни нарвским комендантом караула.

RGADA, coll. 276, inv. 3, f. 211. Report case of Narva port customs about the necessity to build new customs house on the seashore and its costs. 1732. Дело по доношению нарвской портовой таможни о постройке на взморье вместо прежней вновь таможенной конторы.

RGADA, coll. 276, inv. 2, f. 122. Report case of Vyborg zollverwalter Ekermana with companions about founding two more customs posts to restrict smuggling. 1730. Дело по представлению Выборгского цольфальлера Екермана с товарищами об устройстве еще двух застав для предотвращения тайного провоза товаров. 
RGADA, coll. 276, inv. 3, f. 51. Case investigation by Collegium of Commerce of guard soldier Badanin having been beaten by English shipmaster Remsel and merchant Elmesen. 1731. Коммерц-коллегия о расследовании случая избиения караульного солдата Боданина английским шкипером Ремселем и купцом Элмезен.

RGADA, coll. 397, inv. 1, f. 575. Detachment of customs officers on borders to take Shemyakin's report why number of customs post was reduced and other actions by the Supervising Commission over customs duties. 1763. По определению Комиссии смотрения над таможенными сборами, о командировании таможенных служителей на границу, для взятия от обер-инспектора Шемякина рапорт, почему уменьшено число пограничных таможень и прочих его действий.

RGADA, coll. 276, inv. 3, f. 145. Case about the exaction of additional payment from Narva's dwellers Arnse with companions. Дело по экстракту доимочной канцелярии о доимке на нарвских жителях Арнсе с товарищами.

RGADA, coll. 397, inv.2, f. 10. The case of the resolution of the commission on customs on the demand from the Senate of a decree on sending the cases to the Commission to the Commerce Collegium. Дело о резолюции Комиссии о таможнях о требовании из Сената указа об отсылке дел Комиссии в Коммерц-коллегию.

RGADA, coll. 397, inv. 1, f. 569 Case about the writing on 122 pages to supervisor Nikita Shemyakin with companions of delinquent payment. Дело о сочинении обер инспектору Никите шемякину с товарищами о посроченным деньгам ведомости на 122 листах.

RGADA, coll. 276, inv. 3, f. 189. The case of the petition of the foreign merchant of the peasants Miller about the return of various undeclared goods brought to him on the Rostock ship by skipper Petersen. Дело по челобитью иностранного купца крестьян Миллера об отдачи ему привезенных на ростокском корабле шипером Петерсеном разных неявленных товаров.

RGADA, coll. 397, inv. 2, f. 21. Case report for the Admiralty about the confiscation of large number of metal chain shots found on English merchant Pelmer's ship unloading on the merchant jetty in Kronstadt. 1792. Дело по отношению Адмиралтейской колегии о конфискации большого количества металлических книпелей, обнаруженных на судне английского купца Пельмера при его разгрузке на купеческой бирже в Кронштадте.

Complete Collection of Laws of the Russian Empire. Полное собрание законов российской империи. 
Shipmasters, customs, merchants and the Russian coastal experience

\section{Bibliography}

AlCalde Angel, "Spatializing transnational history: European spaces and territories", European Review of History: Revue européenne d'histoire, n 25, 2018, p. 553-567.

Benton Lauren, A Search for Sovereignty: Law and Geography in European Empires, 1400-1900, Cambridge University Press, Cambridge, 2010.

Benton Lauren, Mulich Jeppe, "The Space between Empires: Coastal and Insular Microregions in the Early Nineteenth-Century World", in Sтоск Paul (ed.), The Uses of Space in Early Modern History, Palgrave Macmillan, New York, 2015, p. 151-171.

Bespyatykн Juriy, Arkhangelsk nakanune i v godyi Severnoy voynyi 1700-1721, BLITs, Saint-Petersburg, 2010.

Biskup Marian, "Polen an der Ostsee im 16. Jahrhundert", Zeitschrift für Historische Forschung, n 5/3, 1978, p. 293-314.

Borodkin Mikhail, Dvuhsotletie vzyatiya Vyborga, Gosudarstvennaya tipografiya, St. Petersburg, 1910.

Brenner Robert, "Agrarian Class Structure and Economic Development in Pre-Industrial Europe", Past \& Present, $n^{\circ} 70,1976$, p. 30-75.

Cieslak Edmund, "Aspects of Baltic Sea-borne Trade in the Eighteenth Century: The Trade Relations between Sweden, Poland, Russia and Prussia», Journal of European Economic History, $\mathrm{n}^{\circ}$ 12/2, 1983, p. 239-270.

Demkin Andrej, Britanskoe kupechestvo v Rossii xviii v, Institut Rossiyskoy Istorii, Moscow, 1998.

Elias Otto-Heinrich, "Revaler Handelsschiffahrt im 18. Jahrhundert", Jahrbücher für Geschichte Osteuropas, n 15/1, 1967, p. 16-28.

Jarvis Michael, In the Eye of All Trade: Bermuda, Bermudians, and the Maritime Atlantic World, 1680-1783, University of North Carolina Press, Chapel Hill, 2010.

Kamusella Tomasz, "Germanization, Polonization, and Russification in the partitioned lands of Poland-Lithuania", The Journal of Nationalism and Ethnicity, $\mathrm{n}^{\circ} 41 / 5,2013$, p. 815-838.

Keenan Paul, "A Space between Two Worlds: St. Petersburg in the Early Eighteenth Century", in Sтоск Paul (ed.), The Uses of Space in Early Modern History, Palgrave Macmillan, New York, 2015, p. 97-124.

Kozlova Natalia, Rossiyskiy absolyutizm i kupechestvo v XVIII v.: 20-e - nachalo 60-h godov, Arkheograficheskiy tsentr, Moscow, 1999.

Korchmina Elena, "What Could the Empress Know About Her Money? 
Russian Poll Tax Revenues in the Eighteenth Century", in Frankuin Simon and Bowers Katherine (ed.), Information and Empire: Mechanisms of Communication in Russia, 1600-1850, Open Book Publishers, Cambridge, 2017, p. 287-310.

Land Isaac, "Tidal Waves: The New Coastal History", Journal of Social History, $\mathrm{n}^{\circ}$ 40/3, 2007, p. 731-743.

Lefebvre Henri, La production de l'espace, Anthropos, Paris, 1974.

LodyzHensKi Konstantin, Istoriya russkogo tamozhennogo tarifa, Tipografiya V.S. Balasheva, Saint-Petersburg, 1886.

von Loewe Karl, "Commerce and Agriculture in Lithuania, 1400-1600", The Economic History Review, n” 26/1, 1973, p. 23-37.

Mulich Jeppe, "Microregionalism and Intercolonial Relations: The Case of the Danish West Indies, 1730-1830", Journal of Global History, $\mathrm{n}^{\circ}$ 8/1, 2013, p. 72-94.

Nekrasov Georgiy, Vneshnyaya torgovlya Rossii cherez Revel'skij port v 1721 1756 gg, Nauka, Moscow, 1984.

Redicker Marcus, Between the Devil and the Deep Blue Sea: Merchant Seamen, Pirates and the Anglo-American Maritime World, 1700-1750, Cambridge University Press, Cambridge, 1987.

ReId Phillip, The Merchant Ship in the British Atlantic, 1600-1800, Brill, Leiden, 2020.

Rukhmanova E., "Russko-shvedskaya torgovlya na Baltike v seredine XvII veka”, Skandinavskiy sbornik, $\mathrm{n}^{\circ} 2,1957$, Estonskoye gosudarstvennoye izdatelstvo, Tallinn, p. 52-58.

SeMENov Alexander, Izuchenie istoricheskih svedenij o Rossijskoj vneshnej torgovle i promyshlennosti s poloviny xvii-ogo stoletiya po 1858 god, Vol.1, Tipografiya I.I. Glazunova i Kº Saint-Petersburg, 1859.

Seppel Martin, "The landlords' obligation to maintain their serfs in the Baltic provinces", Social History, $\mathrm{n}^{\circ}$ 8/1, 2009, p. 284-300.

Shasкolsky Igor, "Torgovlya Rossii s Pribaltikoy i Zapadnoy Evropoy v XVII v”, Ekonomicheskie svyazi Pribaltikis Rossiey, Zinatne, Riga, 1968, p. 59-68.

Sоom Arnold, "Die merkantilistische Wirtschaftspolitik Schwedens und die baltischen Städte im 17. Jahrhundert", Jahrbücher für Geschichte Osteuropas, $\mathrm{n}^{\circ} 8 / 1,1963$, p. 183-222.

Stiubhart domhnall Uilleam, "The Making of the Minch: French Pirates, British Herring, and Vernacular Knowledges at an Eighteenth-Century Maritime Crossroads", in Worthington David (ed.), The New Coastal History: Cultural and Environmental Perspectives from Scotland and Beyond, Palgrave Macmillan, New York, 2017, p. 131-148. 
Sтоск Paul, "History and the Uses of Space", in Sтоск Paul (ed.), The Uses of Space in Early Modern History, Palgrave Macmilann, New York, 2015, p. 1-18.

Struve Pavel, Torgovaya politika Rossii, Sotsium, Moscow, 2016.

VICKers Michael, Young Men and the Sea: Yankee Seafarers in the Age of Sail, Yale University Press, New Haven, 2007.

WenzlHuemer Roland, "The ship, the media, and the world: conceptualizing connections in global history", Journal of Global History, n ${ }^{\circ}$ 11, 2016, p. 163-186.

Wezel Katja, "Transcending boundaries: Riga’s Baltic German entrepreneurs in an era of nationalism, revolution, and war", Journal of Baltic Studies, $n^{\circ} 48 / 1$, 2017, p. 39-54.

ZaKHAROv Viktor, Zapadnoevropeyskie kuptsyi v Rossii. Epoha Petra I, ROSSPEN, Moscow, 1996.

\section{L'auteur}

Pavel Demchenko is a PhD student at the Higher School of Economics in St Petersburg, Russia. His research explores maritime trade and commercial practices in the context of the historical development of the Baltic region. He published several articles concerning maritime trade and commercial shipping in the eighteenth century, such as "Destination unknown: The geography of Baltic shipping and the registration system of the Sound Toll Registers in the eighteenth century" International Journal of Maritime History, 2020, https://doi. org/10.1177/0843871420921269 